\title{
SOIL SALINIZATION AND MAIZE AND COWPEA YIELD IN THE CROP ROTATION SYSTEM USING SALINE WATERS
}

\author{
CLAUDIVAN F. LACERDA ${ }^{1}$, GEOCLEBER G. SOUSA ${ }^{2}$, FRANCISCO L. B. SILVA ${ }^{3}$, \\ FRANCISCO V. A. GUIMARÃES ${ }^{4}$, GIOVANA L. SILVA ${ }^{5}$, LOURIVAL F. CAVALCANTE ${ }^{6}$
}

ABSTRACT: The use of saline water and the reuse of drainage water for irrigation depend on longterm strategies that ensure the sustainability of socio-economic and environmental impacts of agricultural systems. In this study, it was evaluated the effects of irrigation with saline water in the dry season and fresh water in the rainy season on the soil salt accumulation yield of maize and cowpea, in a crop rotation system. The experiment was conducted in the field, using a randomized complete block design, with five replications. The first crop was installed during the dry season of 2007, with maize irrigated with water of different salinities $\left(0.8,2.2,3.6\right.$ and $\left.5.0 \mathrm{dS} \mathrm{m}^{-1}\right)$. The maize plants were harvested at 90 days after sowing (DAS), and vegetative growth, dry mass of 1000 seeds and grain yield were evaluated. The same plots were utilized for the cultivation of cowpea, during the rainy season of 2008 . At the end of the crop, cycle plants of this species were harvested, being evaluated the vegetative growth and plant yield. Soil samples were collected before and after maize and cowpea cultivation. The salinity of irrigation water above $2.2 \mathrm{dS} \mathrm{m}^{-1}$ reduced the yield of maize during the dry season. The high total rainfall during the rainy season resulted in leaching of salts accumulated during cultivation in the dry season, and eliminated the possible negative effects of salinity on cowpea plants. However, this crop showed atypical behavior with a significant proportion of vegetative mass and low pod production, which reduced the efficiency of this strategy of crop rotation under the conditions of this study.

KEY WORDS: Zea mays, irrigation, Vigna unguiculata, salt stress.

\section{SALINIZAÇÃO DO SOLO E PRODUTIVIDADE DE MILHO E FEIJÃO CAUPI EM SISTEMA DE ROTAÇÃO CULTURAL UTILIZANDO ÁGUAS SALINAS}

RESUMO: A utilização de águas salinas bem como o reúso de águas de drenagem na irrigação dependem de estratégias de longo prazo que garantam a sustentabilidade socioeconômica e ambiental dos sistemas agrícolas. Neste trabalho, avaliaram-se os efeitos da irrigação com água salina na estação seca e com água de baixa salinidade na estação chuvosa sobre o acúmulo de sais no solo e a produtividade de milho e feijão-de-corda em sistema de rotação. $\mathrm{O}$ experimento foi conduzido em campo, utilizando-se do delineamento em blocos ao acaso, com cinco repetições. O primeiro cultivo foi instalado durante a estação seca de 2007, com a cultura do milho irrigada com água de diferentes

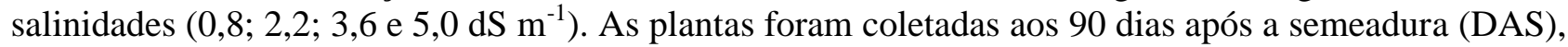
sendo realizadas as avaliações: crescimento vegetativo, produção de grãos por planta, matéria seca de 1.000 grãos e produtividade. Durante a estação chuvosa de 2008, foi cultivado o feijão caupi nas mesmas parcelas que foram cultivadas com milho. Ao final do ciclo, as plantas foram coletadas, sendo realizadas avaliações de crescimento vegetativo e produtividade. Amostras de solo foram coletadas antes e após o cultivo do milho e ao final do cultivo com feijão caupi. A salinidade da água de irrigação acima 2,2 $\mathrm{dS} \mathrm{m}^{-1}$ reduziu a produtividade do milho durante o período seco. Os elevados totais de precipitação pluviométrica durante a estação chuvosa proporcionaram a lixiviação dos sais acumulados durante o cultivo na estação seca e eliminaram os possíveis efeitos negativos da salinidade sobre o feijão caupi. Porém, o feijão caupi apresentou um comportamento atípico com uma expressiva proporção de massa vegetativa e baixa produção de vagens, o que reduziu a eficiência dessa estratégia de rotação de culturas, nas condições do presente estudo.

PALAVRAS-CHAVE: Zea mays, irrigação, Vigna unguiculata, estresse salino.

\footnotetext{
${ }^{1}$ Professor Doutor, Departamento de Engenharia Agrícola, UFC, Fortaleza-CE. Fone: (0xx85) 3366-9756, cfeitosa@ufc.br.

${ }^{2}$ Mestre em Solos e Nutrição de Plantas, UFC, Fortaleza-CE, sousamsa@ yahoo.com.br.

${ }^{3}$ Mestre em Irrigação e Drenagem, UFC, Fortaleza-CE, leandrocmid@ yahoo.com.br.

${ }^{4}$ Doutor em Bioquímica, Gerente do Laboratório de Solo e Água do Departamento de Ciências do Solo, UFC/FUNCEME, FortalezaCE, valderez@ufc.br.

${ }^{5}$ Mestre em Solos e Nutrição de Plantas, UFC, Fortaleza-CE, gisolos@ hotmail.com.

${ }^{6}$ Professor Doutor, Departamento de Solos e Engenharia Rural, UFPB, Areia-PB, lofeca@ cca.ufpb.br.

Recebido pelo Conselho Editorial em: 21-4-2010
}

Aprovado pelo Conselho Editorial em: 2-5-2011

Eng. Agríc., Jaboticabal, v.31, n.4, p.663-675, jul./ago. 2011 


\section{INTRODUCTION}

Irrigation plays an important role in growth and development of plants, which have become essential for the development of agriculture in semiarid regions. However, if not managed properly, irrigation may cause salinization of soils, altering negatively their physical and chemical properties (SILVA et al., 2005; GARCIA et al., 2008).

Salinity is one of the factors that reduces plant growth and productivity worldwide (BAGHALIAN et al., 2008), and each species has a certain level of salinity tolerance, from which the yield begins to decrease linearly; this transition point is called the threshold salinity (AYERS \& WESTCOT, 1999).

In many irrigated areas located in Brazilian semiarid region, the existence of sources of water with electrical conductivities higher than $2.0 \mathrm{dS} \mathrm{m} \mathrm{m}^{-1}$ is common, which are used for irrigation, especially in periods of scarcity of water of good quality. However, the use of such water sources as well as the reuse of drainage water for irrigation depend on long-term strategies to ensure socioeconomic and environmental sustainability of agricultural systems (SHARMA \& RAO, 1998). Among these strategies, the cultivation of tolerant species (PARIDA \& DAS, 2005), the use of leaching fractions (ASSIS JR et al., 2007), the use of saline water in stages higher tolerance of culture (NEVES et al., 2009), and the use of crop rotation with different degrees of salinity tolerance (MURTAZA et al., 2006) are pointed out.

Crop rotation results in beneficial effects on both soil conditions and subsequent crop production (FONTANELI et al., 2000). Crop rotation may be mentioned as beneficial to the improvement of physical, chemical and biological characteristics of soil, weed control, as well as to diseases and pests, the replacement of organic remains, and the protection of soil against the action of climatic agents.

Although there are species that grow well in salty conditions, most cultures are sensitive to salts excess in the soil, and getting more tolerant cultivars is a task not achieved yet. In this sense, the use of crop rotation may be an alternative to semiarid regions of environments (SHARMA \& RAO, 1998; MURTAZA et al., 2006). This strategy appears promising for annual crops, mainly for good drainage soil or that is associated with other strategies that promote leaching, and may contribute to increase the efficiency of land use and soil conservation. Thus, it is possible to use saline water in the dry season and rain water during the wet season, without altering significantly the environment (MURTAZA et al., 2006). The accumulation of salts during the irrigation of crops in the dry season may be reversed, in whole or partially, during the rainy season, considering that this washing process depends on the total annual rainfall, the intensity of rainfall and soil physical properties.

The study aimed to evaluate the effects of irrigation with saline water in the dry season and low salinity water in the rainy season on the accumulation of salts in the soil and productivity of a cycle of crop rotation with maize and cowpea.

\section{MATERIAL AND METHODS}

The study of crop rotation with maize (Zea mays L.) and cowpea (Vigna unguiculata L. Walp) was conducted in the field, a Alfissol (EMBRAPA, 2006) at the experimental area of the Laboratory of Hydraulics and Irrigation at the Federal University of Ceará, Pici Campus, Fortaleza, Ceará ( $\left.3^{\circ} 45^{\prime} \mathrm{S} ; 38^{\circ} 33^{\prime} \mathrm{W}, 20 \mathrm{~m}\right)$, Brazil. According to the Köppen classification, the climate of the region is Aw'. The textural classification and the main chemical characteristics of the soil before the experiment are presented in Table 1. 
TABLE 1. Chemical characteristics and textural class of soil before the installation of treatments, related to maize crop.

\begin{tabular}{lccc}
\hline Characteristics & \multicolumn{3}{c}{ Layers $(\mathrm{cm})$} \\
\cline { 2 - 4 } & $0-30$ & $30-60$ & $60-90$ \\
\cline { 2 - 4 } Textural Class & Sandy Loams & Sandy-Clay Loams & Sandy-Clay Loams \\
\hline Soil Density $\left(\mathrm{kg} \mathrm{dm}^{-3}\right)$ & 1.40 & 1.41 & 1.29 \\
$\mathrm{Ca}^{2+}\left(\mathrm{cmol}_{\mathrm{c}} \mathrm{dm}^{-3}\right)$ & 1.5 & 0.9 & 1.5 \\
$\mathrm{Mg}^{2+}\left(\mathrm{cmol}_{\mathrm{c}} \mathrm{dm}^{-3}\right)$ & 1.1 & 0.8 & 1.5 \\
$\mathrm{~K}^{+}\left(\mathrm{mg} \mathrm{dm}^{-3}\right)$ & 0.11 & 0.08 & 0.06 \\
$\mathrm{Na}^{+}\left(\mathrm{cmol}_{\mathrm{c}} \mathrm{dm}^{-3}\right)$ & 0.26 & 0.41 & 0.26 \\
$\mathrm{H}+\mathrm{Al}\left(\mathrm{cmol}_{\mathrm{c}} \mathrm{dm}^{-3}\right)$ & 1.15 & 1.81 & 1.32 \\
$\mathrm{Al}^{3+}\left(\mathrm{cmol}_{\mathrm{c}} \mathrm{dm}^{-3}\right)$ & 0.05 & 0.2 & 0.15 \\
$\mathrm{ESP}(\%)^{1}$ & 6 & 10 & 5 \\
$\mathrm{pH}\left(\mathrm{H}_{2} \mathrm{O} 1: 2,5\right)$ & 6.3 & 5.2 & 5.2 \\
$\mathrm{EC}$ & $\left.0.1: 1(\mathrm{dS} \mathrm{m})^{-1}\right)^{2}$ & 0.4 & 0.28 \\
\hline
\end{tabular}

${ }^{1} \mathrm{ESP}=$ exchangeable sodium percentage $;{ }^{2} \mathrm{EC}=$ electrical conductivity of the extract soil: water

The study lasted seven months, in which the first crop was installed during the dry season (from September to December of 2007) with the cultivation of the hybrid maize AG 1051, using water with different concentrations of salts in irrigation, ranging from 0.8 to $5.0 \mathrm{dS} \mathrm{m}^{-1}$. During the rainy season (from January to April of 2008), the cowpea cultivar EPACE 10 was cultivated, holding only two additional irrigations (total of $40 \mathrm{~mm}$ ) with water of low salinity during an Indian summer at the beginning of February. The monthly weather data and the ten-day period distribution of precipitation are in Table 2 and Figure 1, respectively.

TABLE 2. Mean values of temperature (T), relative humidity (RH), wind speed (S), and totals of insolation and precipitation (PPT) obtained during the dry season (maize crop) and during the subsequent rainy season (growing cowpea).

\begin{tabular}{cccccc}
\hline Months & $\mathrm{T}\left({ }^{\circ} \mathrm{C}\right)$ & $\mathrm{RH}(\%)$ & $\mathrm{S}\left(\mathrm{m} \mathrm{s}^{-1}\right)$ & Insolation $(\mathrm{h})$ & PPT $(\mathrm{mm})$ \\
\hline Sep/07 & 27.0 & 67 & 4.1 & 308.1 & 14 \\
Oct/07 & 27.2 & 67 & 4.2 & 313.6 & 0.9 \\
Nov/07 & 27.7 & 70 & 4.3 & 332.5 & 5.0 \\
Dec/07 & 27.7 & 73 & 3.5 & 254.5 & 87.5 \\
Jan/08 & 26.6 & 83 & 1.4 & 141.8 & 287.7 \\
Feb/08 & 27.8 & 75 & 3.0 & 257.6 & 75.3 \\
Mar/08 & 27.0 & 79 & 2.9 & 211.8 & 282.7 \\
Apr/08 & 26.6 & 85 & 1.5 & 113.4 & 521.5 \\
\hline
\end{tabular}

Source: Federal University of Ceará's Weather Station

The seeds of AG 1051 were germinated in the field, and after the establishment, eight days after sowing (DAS), plants were irrigated with water with four different electrical conductivities: 0.8 (deep well water), 2.2 (T2), 3.6 (T3) and $5.0 \mathrm{dS} \mathrm{m}^{-1}$ (T4). For T2, T3 and T4, the salts $\mathrm{NaCl}$, $\mathrm{CaCl}_{2} \cdot 2 \mathrm{H}_{2} \mathrm{O} \mathrm{MgCl}_{2} \cdot 6 \mathrm{H}_{2} \mathrm{O}$ were added to well water and dissolved in the proportion of $7: 2: 1$, according to the relationship between $\mathrm{ECa}$ and its concentration $\left(\mathrm{mmol}_{\mathrm{c}} \mathrm{L}^{-1}=\mathrm{EC} \times 10\right)$, according to RHOADES et al. (2000) and MEDEIROS (1992). 


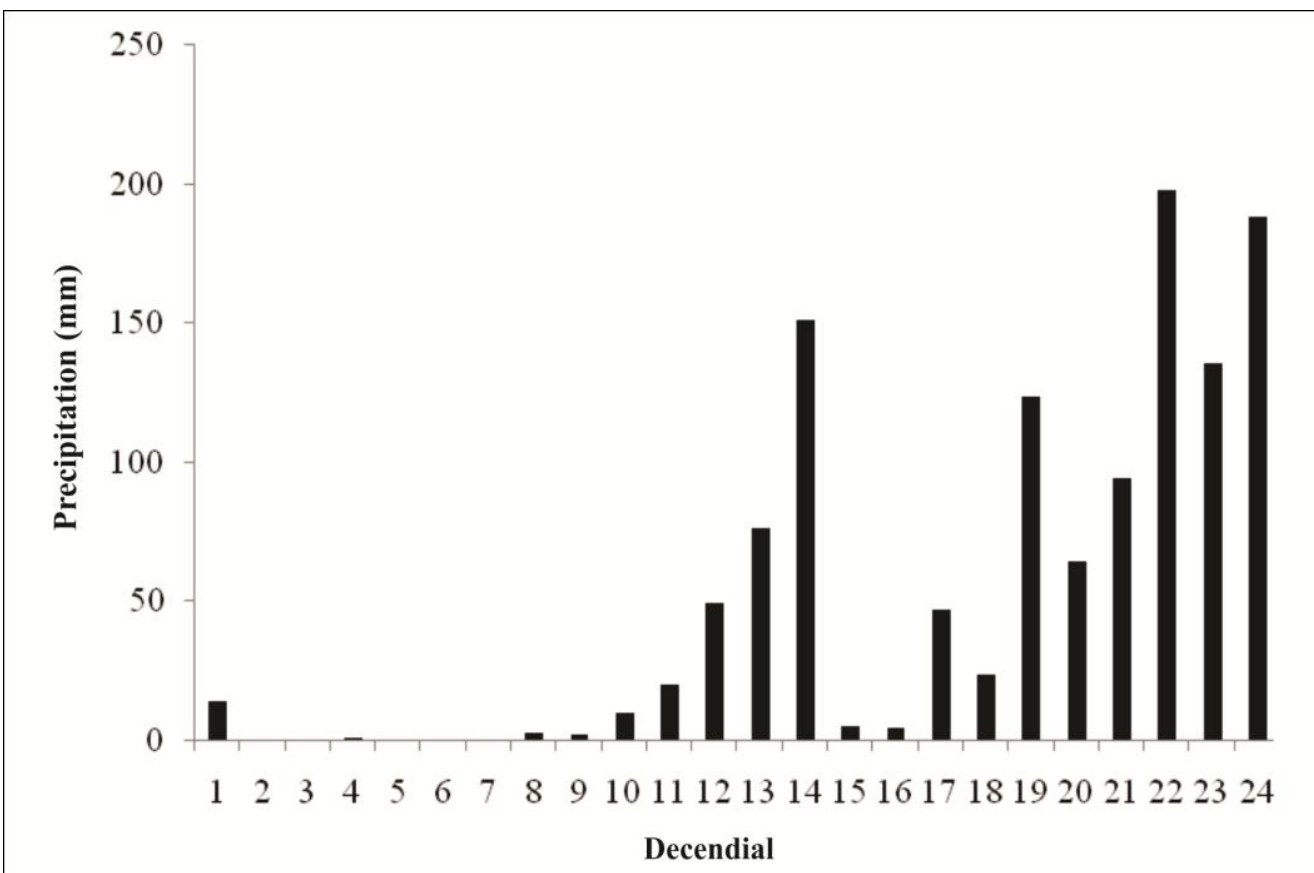

FIGURE 1. The precipitation each ten days on the period between September/2007 to April/2008. The maize was grown between $1^{\text {st }}$ and $11^{\text {th }}$ periods of ten days, while the cowpea from $15^{\text {th }}$ to $24^{\text {th }}$.

The water was applied in leveled furrows and closed in irrigation interval of three days. The irrigation depths were set based on the values of evapotranspiration of reference (ETo) obtained through the tank class A, and the crop coefficient $(\mathrm{Kc})$ recommended for the different phenological stages of the crop (DOORENBOS \& KASSAM, 1994). It was also added a leaching fraction of $15 \%$, calculated according to AYERS \& WESTCOT (1999). The fertilization followed the recommendation of FERNANDES (1993), applying doses of 60, 30 and $30 \mathrm{~kg} \mathrm{ha}^{-1}$ of $\mathrm{P}_{2} \mathrm{O}_{5}$ and $\mathrm{K}_{2} \mathrm{O}$, respectively.

The experimental design consisted of randomized blocks, with five repetitions, in a total of 20 experimental units. Each plot of plantation was $3 \mathrm{~m}$ long and five rows. A spacing of $0.8 \times 0.2 \mathrm{~m}$, with 1,600 plants in total, and a planting density of 62,500 plants per hectare were used.

To the 90 DAS, groups of 15 plants selected at random within the plot area (represented by the three central rows) were separated into leaf, colm + sheath, and cob, packed in paper bags and taken to a greenhouse with forced air ventilation, at $65{ }^{\circ} \mathrm{C}$ until constant weight. The variables assessed were: dry matter production of vegetative and reproductive parts, crop yield, 1,000 grain weight and dry matter partitioning in the shoot.

The second planting occurred in the rainy season with cowpea, cultivar EPACE 10, and supplementary irrigation was performed early in the crop cycle. Culture was performed on the same plots that were previously cultivated with maize, and were applied doses of 20,60 and $30 \mathrm{~kg} \mathrm{ha}^{-1}$ of $\mathrm{N}, \mathrm{P}_{2} \mathrm{O}_{5}$ and $\mathrm{K}_{2} \mathrm{O}$, respectively (FERNANDES, 1993). The spacing used was $0.8 \times 0.3 \mathrm{~m}$ with two plants per hole and planting density of 83,333 plants $^{-1}$.

At the end of the cycle (about 80 to 90 DAS) harvests of all mature pods were held in three central rows of the useful parcel, which were taken for drying in a greenhouse of forced air circulation at $65^{\circ} \mathrm{C}$. The dry mass of pods (PODDM), the number of grains per pod, the mean size of the pods and the weight of 1,000 grains were evaluated. The grain yield was also estimated in $\mathrm{kg}$ $\mathrm{ha}^{-1}$, multiplying the yield per plant by planting density.

To obtain the dry mass production of the vegetative parts, plants contained in an area of 1.0 $\mathrm{m}^{2}$ were harvested, also useful within the plot, being the area bounded by a quadrant thrown at 
random in each plot. The use of this methodology was necessary because of the great synergy of plants that did not allow the harvesting of plants individually. The harvested plants were separated into leaf and stems (stems + petioles). For determination of dry matter, homogeneous samples of approximately $200 \mathrm{~g}$ were collected from different parts were packed in paper bags and, after dried at $65^{\circ} \mathrm{C}$ at the greenhouse, were weighed to obtain dry matter yield. The dry matter production was obtained by multiplying the fresh weight of each part taken by the respective quadrant dry matter content. The vegetative dry mass (VEGDM) was obtained by the sum of leaf and stems.

With data from dry matter production of each part of the plant (PODDM and VEGDM), the production of dry matter of the area (DMS) was obtained, and the partitioning of dry matter between vegetative and reproductive parts were calculated.

Before and after maize cultivation and after the cultivation of the cowpea, sub-samples were collected in soil layers of 0 to $0.30,0.30$ to 0.60 and from 0.60 to $0.90 \mathrm{~m}$ in five plots of each treatment, which were then homogenized, forming a composite sample just from treatment, and used in the determination of electrical conductivity in 1:1 extract (soil:water) and the exchangeable sodium percentage (ESP), according to EMBRAPA (1999). The samples were collected from plants in the middle third of the central row of each plot.

Data from the cultivation of maize were submitted to analysis of variance and regression using the computer program SAEG/UFV (RIBEIRO JÚNIOR, 2001). Analysis of variance was also used to evaluate the effect of residual salts in the soil about the cowpea.

\section{RESULTS AND DISCUSSION}

\section{Accumulation of salts in the soil}

Increasing salinity of irrigation water during the cultivation of maize resulted in increases in $\mathrm{EC}_{1: 1}$ soil in the three evaluated layers (Table 3), in comparison with data obtained before the experiment (Table 1), with the largest values being recorded in the layer from 0.30 to $0.60 \mathrm{~m}$. The electrical conductivity values measured after the rainy season decreased after all treatments, as a result of the rainfall occurred from January to April of 2008. This washing effect due to the rainy season was similar to that observed in other studies (MURTAZA et al., 2006; ASSIS JÚNIOR et al., 2007; BEZERRA et al., 2010).

TABLE 3. Electrical conductivity of soil/water $\left(\mathrm{EC}_{1: 1}\right)$ extract and exchangeable sodium percentage (ESP) in samples from different depths of a Yellow Red Argisol, irrigated with saline waters.

\begin{tabular}{|c|c|c|c|c|c|c|}
\hline \multirow{2}{*}{$\begin{array}{c}\mathrm{ECa} \\
\left(\mathrm{dS} \mathrm{m}^{-1}\right)\end{array}$} & \multicolumn{3}{|c|}{$\mathrm{EC} 1: 1\left(\mathrm{dS} \mathrm{m} \mathrm{m}^{-1}\right)$} & \multicolumn{3}{|c|}{$\operatorname{ESP}(\%)$} \\
\hline & $0-0.3 \mathrm{~m}$ & $0.3-0.6 \mathrm{~m}$ & $0.6-0.9 \mathrm{~m}$ & $0-0.3 \mathrm{~m}$ & $0,3-0.6 \mathrm{~m}$ & $0.6-0.9 \mathrm{~m}$ \\
\hline & \multicolumn{6}{|c|}{ December, 2008 (after maize cultivation) } \\
\hline 0.8 & 0.69 & 0.79 & 0.50 & 19 & 20 & 16 \\
\hline 2.2 & 0.95 & 1.58 & 1.49 & 23 & 20 & 22 \\
\hline 3.6 & 1.56 & 2.01 & 1.50 & 30 & 23 & 23 \\
\hline 5.0 & 1.62 & 2.70 & 1.89 & 25 & 25 & 24 \\
\hline \multicolumn{7}{|c|}{ April, 2008 (after cowpea cultivation) } \\
\hline $0.8^{\#, \mathrm{a}}$ & 0.29 & 0.22 & 0.3 & 3 & 2 & 3 \\
\hline $0.8^{\#, \mathrm{~b}}$ & 0.31 & 0.27 & 0.4 & 4 & 6 & 8 \\
\hline $0.8^{\#, \mathrm{c}}$ & 0.27 & 0.29 & 0.37 & 4 & 7 & 7 \\
\hline $0.8^{\#, \mathrm{~d}}$ & 0.17 & 0.15 & 0.27 & 3 & 7 & 6 \\
\hline
\end{tabular}

After the cultivation of maize, the values of exchangeable sodium percentage (ESP) were superior to the limit of ESP used to classify sodium soils, which is 15\% (RICHARDS, 1954) in 
almost all soil depths (Table 3). This can compromise the ESP high soil structure and, consequently, the development of plant roots, considering that the observed increases are mostly due to the composition of saline water used for irrigation, which had a ratio of $7: 3$ of $\mathrm{Na}^{+}$on the main divalent cations $\left(\mathrm{Ca}^{+2} \mathrm{e} \mathrm{Mg}^{+2}\right)$. After the passage of the rainy season, the values of ESP decreased in all soil depths, as a result of leaching of the sodium layers evaluated.

The results obtained in relation to $\mathrm{EC}_{1: 1}$ and ESP reinforce the need for field studies on the use of saline water for irrigation, which allow the assess of the actual effects of different management practices used, as well as the local climatic conditions, the variations in the accumulation of salts and the possible impacts on plants (MURTAZA et al. 2006; LEITE et al., 2007; ASSIS JÚNIOR et al., 2007; LACERDA et al., 2009; BEZERRA et al., 2010). These studies contribute to the coexistence and to the better understanding of the problems of salinity and sodicity in irrigated agriculture (AGUIAR NETO et al., 2008; RITZEMA et al., 2008).

\section{Growth and productivity of maize}

Salinity affected the dry matter of culms + sheath (DMCS), leaf (DML), shoot part(DMSP) and cob (DMC) (Table 4), showing the effects of salts in irrigation water applied during the culture cycle and the moderate sensitivity of the maize culture to salinity (AYERS \& WESTCOT, 1999).

TABLE 4. Square values and statistical significance of the dry matter production of culms + sheaths (DMCS), leaf blades (DML), shoot part (DMSP) and cobs (DMC) in maize plants irrigated with water with four levels of salinity.

\begin{tabular}{ccccc}
\hline Productivity & \multicolumn{3}{c}{ Mean Squares } & VC \\
\cline { 2 - 4 } components & Treatments & Blocks & Residue & $\%$ \\
\cline { 2 - 4 } DMCS & $145.5^{* * *}$ & $25.8^{\mathrm{ns}}$ & 15.9 & 8.3 \\
DML & $129.2^{* *}$ & $9.8^{\mathrm{ns}}$ & 6.2 & 11.1 \\
DMSP & $1586.6^{*}$ & $206.9^{\mathrm{ns}}$ & 340.9 & 9.7 \\
DMC & $720.3^{*}$ & $132.9^{\mathrm{ns}}$ & 222.2 & 13.3 \\
\hline
\end{tabular}

${ }^{\mathrm{ns}}=$ Not significant; $* * *=$ significant at 5 and $1 \%$ level by the test $\mathrm{F} ; \mathrm{CV}=$ variation coefficient.

To DMCS, DMSP and DMC (Figures 2A, 2C and 2D), the reduction of the dry mass was evident in plants subjected to electrical conductivity greater than $2.2 \mathrm{ds} \mathrm{m}^{-1}$, while DML (Figure 2B) decreased linearly with increasing of ECa. This growth inhibition is partially due to the metabolic costs associated with an attempt to adapt the plant to salinity.

Similar results were found by GARCIA et al. (2007b) e OLIVEIRA et al. (2009) in maize cultures in greenhouse conditions. The results of this study, however, reveal a greater degree of tolerance of maize culture compared to data from the FAO, which considers the threshold water salinity of $1.1 \mathrm{dS} \mathrm{m}^{-1}$ with leaching fraction of 0.15 (AYERS \& WESTCOT, 1999).

This can be explained partly by the existence of genetic variability among maize cultivars in response to salt stress (AZEVEDO NETO et al., 2004) and because the irrigation with saline water has started only after the germination and seedling establishment, phases of higher sensitivity of maize to salinity (MAAS \& HOFFMAN, 1977). 

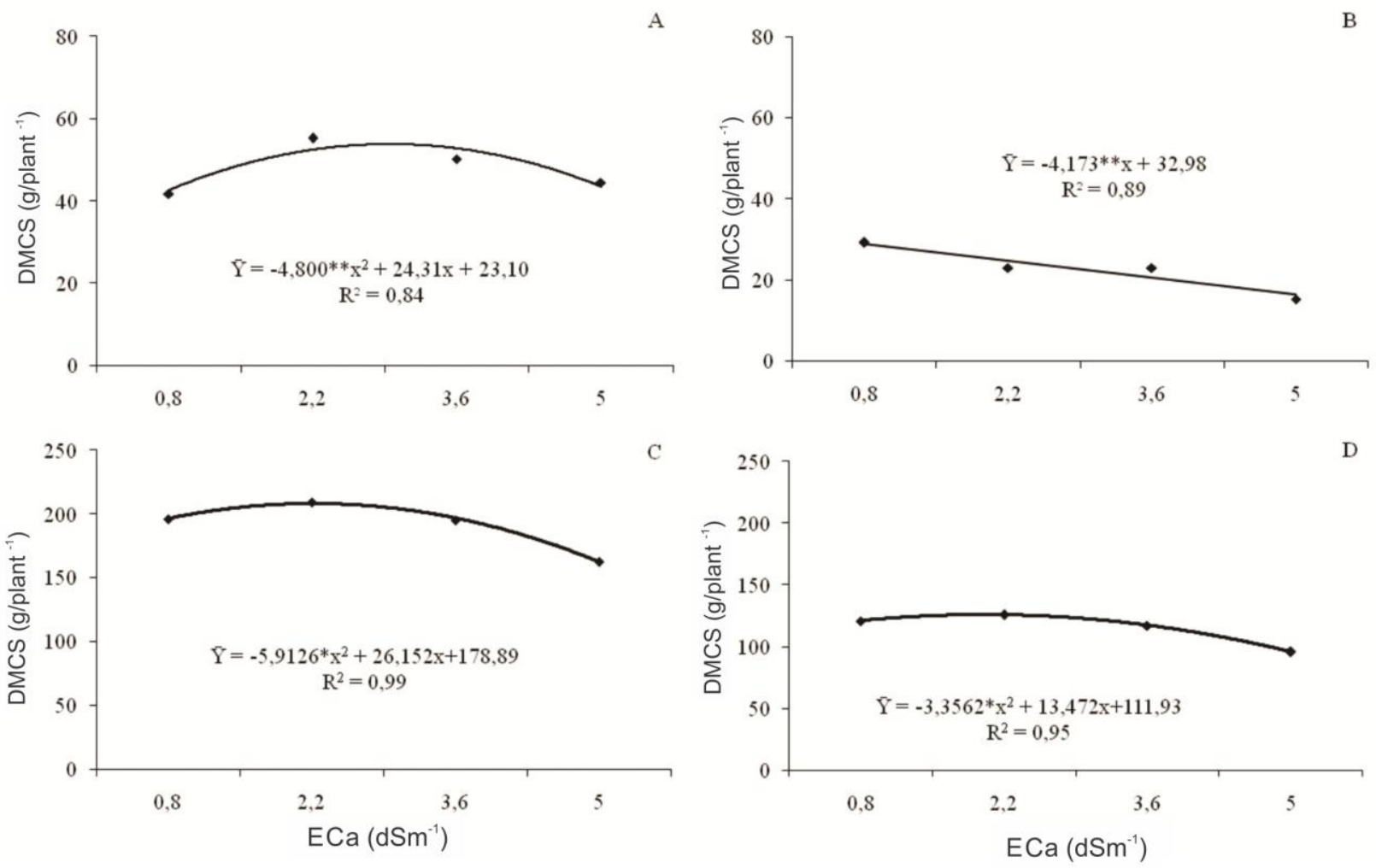

FIGURE 2. Dry matter of colm + sheath (DMCS) (A), leaf blades (DML) (B), shoot part (DMSP) (C) and dry weight of the cubs (DMC) (D) in maize plants irrigated with water increasing salt concentrations.

The increase of salts in irrigation water affected the dry matter of grain (DMGR), but did not influence the dry matter of the cob (DMC), straw (DMST) and the 1,000 grain weight (W 1000G) (Table 5). The dry matter production of grains (Figure 3) decreased due to the increasing of the concentration of salts in irrigation water. The action of these salts can go beyond a simple decrease in soil water potential to cellular injury caused by oxidative stress in plants (GARCIA et al., 2007b), and these effects together result in reduced productivity (FERREIRA et al., 2007; AGUIAR NETO et al., 2008; BLANCO et al., 2008).

TABLE 5. Mean square values and statistical significance of the production of dry grains (DMGR), cub (DMC) and straw (DMST), and dry weight of 1000 seeds (W1000) in maize plants irrigated with water of increasing concentrations of salts.

\begin{tabular}{lcccc}
\hline Productivity & \multicolumn{3}{c}{ Mean Squares } & \multirow{2}{*}{ VC\% } \\
\cline { 2 - 4 } components & Treatments & Blocks & Residue & 15.3 \\
\cline { 2 - 3 } DMGR & $387.6^{*}$ & $34.8^{\mathrm{ns}}$ & 89.4 & 13.7 \\
DMC & $12.4^{\mathrm{ns}}$ & $9.4^{*}$ & 2.3 & 17.4 \\
DMST & $121.9^{\mathrm{ns}}$ & $17.3^{\mathrm{ns}}$ & 52.8 & 10.1 \\
W1000 & $75.8^{\mathrm{ns}}$ & $482.4^{\mathrm{ns}}$ & 293.9 & \\
\hline${ }^{\mathrm{ns}}=$ Not significant; ${ }^{*}=$ significant at $5 \%$ level by the test F; $\mathrm{VC}=$ variation coefficient.
\end{tabular}

The yields obtained were 4,362, 4,366, 3,606 and 3,110 $\mathrm{kg}^{-1}$ respectively for $\mathrm{T} 1$, T2, T3 and T4. Yields obtained with water of low salinity $\left(0.8 \mathrm{dS} \mathrm{m}^{-1}\right)$ and with saline water with CEa of $2.2 \mathrm{~m}^{-1}$ are above the average productivity of $3,260 \mathrm{~kg} \mathrm{ha}^{-1}$ in Brazil and higher productivity average of $4,000 \mathrm{~kg} \mathrm{ha}^{-1}$ of the United States, which is the largest producer (FORNASIERI FILHO, 2007). 


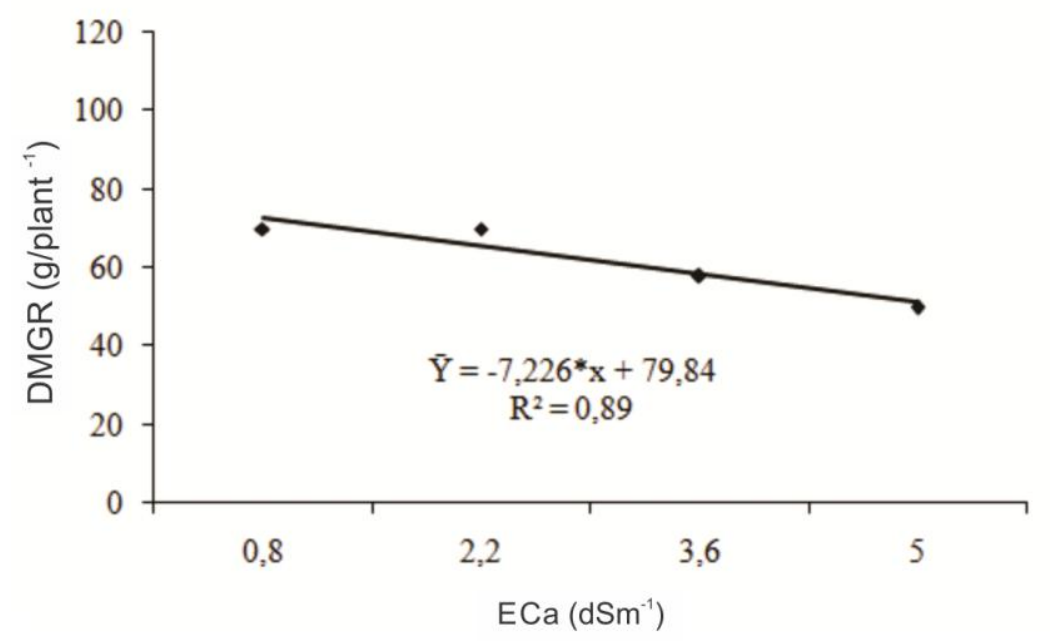

FIGURE 3. Dry matter production of grain in maize plants irrigated with saline water.

The distribution of dry matter in different parts of the plant was significantly affected by salinity of irrigation water. Irrigation with increasing values of salinity increased the proportion of stem and dead material, and reduced the partition of leaf dry matter and harvest index (Tables 6 and 7). Changes in the percentage distribution of dry matter caused by salt stress are consistent with the fact that the salinity, besides reducing the total biomass, might also change the partition of photoassimilates between different parts of plants (GARCIA et al., 2007a). The increase in the proportion of stems and reduced leaf production (Table 6) resulted in a decrease in the source/drains, which may limit the productive capacity of plants. These results, however, differ from those obtained by LACERDA et al. (2006) e AQUINO et al. (2007) for cowpea and sorghum, respectively, who observed an increase in the proportions between sources and drains in the plants subjected to salt stress.

TABLE 6. Mean square values and statistical significance of the partition of dry matter in different parts of maize plants irrigated with water of increasing concentrations of salts

\begin{tabular}{ccccc}
\hline \multirow{2}{*}{ Variables } & \multicolumn{3}{c}{ Mean Squares } & VC \\
\cline { 2 - 4 } Culms + sheath & Treatments & Blocks & Residue \\
\cline { 2 - 3 } Leaf & $0.30^{* * *}$ & $0.04^{\text {ns }}$ & 0.04 & 4.1 \\
Tassel & $0.47^{* *}$ & $0.10^{\text {ns }}$ & 0.04 & 5.6 \\
Straw & $0.03^{\text {ns }}$ & $0.003^{\text {ns }}$ & 0.012 & 9.5 \\
Cob & $0.082^{\text {ns }}$ & $0.019^{\text {ns }}$ & 0,053 & 5.0 \\
Dead material & $0.25^{*}$ & $0.058^{\text {ns }}$ & 0.042 & 8.4 \\
Grains (HI) & $0.38^{* *}$ & $0.011^{\text {ns }}$ & 0.016 & 10.4 \\
\hline ns & $0.23^{*}$ & $0.008^{\text {ns }}$ & 0.059 & 4.3 \\
\hline
\end{tabular}

${ }^{\mathrm{ns}}=$ Not significant; ${ }^{*}=$ significant at $5 \%$ level by the test $\mathrm{F} ; \mathrm{VC}=$ variation coefficient.

TABLE 7. Partition of dry matter of the shoot part in maize plants irrigated with water of increasing concentrations of salts

\begin{tabular}{cccccccc}
\hline $\begin{array}{c}\text { ECa } \\
\left(\mathrm{dS} \mathrm{m}^{-1}\right)\end{array}$ & \multicolumn{7}{c}{ Percentage $^{1}$} \\
& $\begin{array}{c}\text { culms+ } \\
\text { sheath }\end{array}$ & Leaf & Tassel & Straw & Cob & $\begin{array}{c}\text { Dead } \\
\text { material }\end{array}$ & HI $^{2}$ \\
\cline { 2 - 7 } 0.8 & $21.4 \pm 1.3$ & $15.1 \pm 2.3$ & $1.1 \pm 0.3$ & $20.1 \pm 1.1$ & $5.8 \pm 1.1$ & $1.1 \pm 0.2$ & $35.5 \pm 2.6$ \\
2.2 & $26.4 \pm 2.2$ & $10.9 \pm 1.1$ & $1.4 \pm 0.2$ & $22.3 \pm 1.1$ & $4.4 \pm 1.5$ & $1.2 \pm 0.3$ & $33.4 \pm 1.9$ \\
3.6 & $25.7 \pm 1.3$ & $11.8 \pm 2.1$ & $1.5 \pm 0.2$ & $23.3 \pm 3.0$ & $6.9 \pm 0.5$ & $1.3 \pm 0.4$ & $29.6 \pm 1.7$ \\
5.0 & $27.6 \pm 3.0$ & $9.4 \pm 0.5$ & $1.5 \pm 0.2$ & $21.5 \pm 2.2$ & $6.6 \pm 0.2$ & $2.9 \pm 0.3$ & $30.5 \pm 3.2$ \\
\hline
\end{tabular}

${ }^{1}$ means \pm standard error; $\mathrm{n}=5 ;{ }^{2} \mathrm{HI}=$ Harvest index 


\section{Growth and yield of cowpea}

Overall, it appears that the accumulation of sodium and salts in the soil for the cultivation of maize (Table 3) were not sufficient to cause effects on growth and productivity of cowpea during the subsequent rainy season (Tables 8 and 9). This was mostly due to the total of about $250 \mathrm{~mm}$ of rainfall in the period between the cultivation of maize and cowpea. During the experiment of the cowpea (25 January to 25 April of 2008), a large amount of precipitation (900 mm) was also found, and of 25 days of the month of April only on three of them no precipitation occurred. These rains have provided a good leaching of salts, both before and during the rainy season cultivation. Similar results were obtained by MURTAZA et al. (2006) and BEZERRA et al. (2010), studying systems of crop rotation on cotton/wheat and cowpea/maize, respectively, both irrigated with water of low and high salinity.

TABLE 8. Mean square values and statistical significance of dry matter from vegetative parts (VEGDM), of pod (PODDM), of shoot part (DMSP), of pod size (PS), seeds per pod (GRPOD) and weight of 100 seeds (W 1000) of bean cowpea plants grown in experimental plots that were previously planted with maize.

\begin{tabular}{|c|c|c|c|c|}
\hline \multirow{2}{*}{ Parameters } & \multicolumn{3}{|c|}{ Mean Squares } & \multirow{2}{*}{$\begin{array}{c}\mathrm{VC} \\
\%\end{array}$} \\
\hline & Treatments & Blocks & Residue & \\
\hline VEGDM & $105.0^{\mathrm{ns}}$ & $129.0^{\mathrm{ns}}$ & 43.0 & 15.0 \\
\hline PODDM & $0.425^{\mathrm{ns}}$ & $0.26^{\mathrm{ns}}$ & 0.255 & 23.0 \\
\hline DMSP & $284.0^{\mathrm{ns}}$ & $394.8^{*}$ & 84.1 & 12.7 \\
\hline PS & $0.592^{\mathrm{ns}}$ & $0.135^{\mathrm{ns}}$ & 0.695 & 4.5 \\
\hline GRPOD & 2.450 & 0.075 & 4.741 & 19.2 \\
\hline W100 & $0.419^{\mathrm{ns}}$ & $0.618^{\mathrm{ns}}$ & 1.257 & 8.1 \\
\hline
\end{tabular}

TABLE 9. Dry matter of the vegetative parts (VEGDM), of pods (PODDM) and of shoot part (DMSP) of cowpea plants grown in experimental plots that were previously planted with maize.

\begin{tabular}{cccc}
\hline \multirow{2}{*}{ ECa $\left(\mathrm{dS} \mathrm{m}{ }^{-1}\right)$} & \multicolumn{3}{c}{ Dry matter $\left(\mathrm{g}\right.$ plant $\left.{ }^{-1}\right)$} \\
\cline { 2 - 4 } $0.8^{\#, \mathrm{a}}$ & VEGDM & PODDM & DMSP \\
\cline { 2 - 4 } $0.8^{\#, \mathrm{~b}}$ & $63.0 \pm 2.7^{1}(96.3)^{2}$ & $2.4 \pm 0.6(3.7)$ & $65.4 \pm 2.7$ \\
$0.8^{\#, \mathrm{c}}$ & $70.5 \pm 5.3(96.1)$ & $2.8 \pm 0.6(3.9)$ & $71.0 \pm 6.4$ \\
$0.8^{\#, \mathrm{~d}}$ & $66.3 \pm 7.9(95.8)$ & $2.4 \pm 1.0(3.2)$ & $72.9 \pm 6.0$ \\
\end{tabular}

${ }^{1}$ means \pm standard error; $\mathrm{n}=5 ;{ }^{2}$ the values in parentheses represent the percentage regarding the dry matter of the total area ${ }^{\#}$ Irrigated with water from a Treatment $1\left(\mathrm{ECa}=0,8 \mathrm{dS} \mathrm{\textrm {m } ^ { - 1 } )}\right.$ on an additional plots previously irrigated with waters of $0.8 ; 2.2 ; 3.6$ e $5.0 \mathrm{dS} \mathrm{m}^{-1}\left({ }^{\mathrm{a}, \mathrm{b}, \mathrm{c}, \mathrm{d}}\right.$, respectively).

Although the rains have provided the leaching of salts from the soil (Table 2), it appears that the cowpea had an atypical behavior with a significant proportion of vegetative mass and low pod production (Table 9). The estimated yield based on yield per plant and on the density of planting were 160, 181, 168 and $169 \mathrm{~kg} \mathrm{ha}^{-1}$, respectively for T1, T2, T3 and T4. These values are well below those reported for the cultivar EPACE 10 under rainfed conditions (FREIRE-FILHO et al., 2005). Studies conducted with this cultivar in the same soil conditions, but under irrigation during the dry season, also showed a very different pattern of development, with a yield above $1,800 \mathrm{~kg} \mathrm{ha}^{-}$ 1 , with the dry grain representing between 35 and $48 \%$ of dry matter of the shoot part (ASSIS JÚNIOR et al., 2007; BEZERRA et al., 2010; NEVES et al., 2010). In addition to low productivity, the extension of the crop cycle was verified in the present study, with about 15 days over the maximum characteristic of this cultivar, which is 75 days (FREIRE-FILHO et al., 2005). 
The cowpea yields well under irrigation conditions with blades ranging from 300 to $450 \mathrm{~mm}$ (ANDRADE JUNIOR et al., 2002; EMBRAPA MEIO NORTE, 2003). Under rainfed conditions, it is considered that a total precipitation of 250 to $500 \mathrm{~mm}$ results in high (EMBRAPA MEIO NORTE, 2003), although many authors emphasize that the distribution of rainfall throughout the cycle may be more important than the total rainfall (ALVES et al., 1982). In addition, there are differences between cultivars, with some proving more sensitive to drought and others that are very sensitive to excess of water, and these responses also depend on the length of the cycle and the growth habit of these genotypes (ALVES et al., 1982; TIMSINA et al., 1994). In this study, rainfall was about two times higher than the average water demand of culture, with lots of rain during flowering and fruiting (Figure 1), which may have contributed to the low yields obtained.

Although grain production has been very low compared to those observed in other studies, the same cannot be said in relation to the total dry matter production of shoots (Table 9). Crops irrigated during the dry season, with the same cultivar in the same area, showed dry matter of shoot area of 55 (NEVES et al., 2009), 63 (BEZERRA et al., 2010) and $80 \mathrm{~g} \mathrm{plant}^{-1}$ (ASSIS JÚNIOR et al., 2007), which did not differ much from the values observed in this study (Table 9). These similarities in the accumulation of dry matter are indicative that plants were not subject to flooding, since this stress factor causes dramatic reductions in carbon assimilation and growth of cowpea (TIMSINA et al., 1994). So, what the study verified was a change in the partition of carbon in the plant, with reductions of about 10 times in the harvest index (Table 9), in relation to the results obtained in the dry season (ASSIS JÚNIOR et al., 2007; BEZERRA et al., 2010; NEVES et al., 2010).

In soybean plants, species of the same family as the cowpea, the balance between vegetative and reproductive growth is considered one of the main factors of production, and the change affects the balance of their crop yield (MUNDSTOCK \& THOMAS, 2005). According to these authors, the growth, development and production of grains resulting from the interaction between cultivar and environmental factors, such as sensitivity to photoperiod, air temperature, the lodging and the excess or shortage of water, considering that the excess water, often in high rainfall years, reflect in excessive vegetative growth, with the plants producing lots of green mass and fewer grains. Therefore, it is possible to suggest that changes in weather elements and maintenance of high levels of soil moisture, associated with heavy rainfall, especially during flowering and fruiting, have helped to change the pattern of development of the culture of cowpea under the conditions of this study.

\section{CONCLUSIONS}

Increasing salinity of irrigation water above $2.2 \mathrm{dS} \mathrm{m}^{-1}$ reduced the productivity of maize during the dry season;

The high total rainfall during the rainy season provided the leaching of salts accumulated during the cultivation of maize in the dry season and eliminated the possible negative effects of salinity on cowpea, but the cowpea showed atypical behavior with a significant proportion of mass vegetative and low pod production, which reduced the efficiency of this strategy of crop rotation, in accordance with this study.

\section{REFERENCES}

AGUIAR NETO A.O.; GOMES, C.C.S.; LINS; C.C.V.; BARROS, A.C.; CAMPECHE; L.F.S.M.; BLANCO, F.F. Características químicas e salino-sodicidade dos solos do Perímetro Irrigado Califórnia, SE, Brasil. Ciência Rural, Santa Maria, v.37, n.6, p.1.640-1.645, 2007.

ALVES, J.F.; SANTOS, J.H.R.; OLIVEIRA, F.J.; TEÓFILO, E.M. Estabilidade fenotipica e adaptação de cultivares de cowpea, Vigna sinensis (1.) Savi. Ciência Agronômica, Fortaleza, v.13, n.1-2, p.53-59, 1982. 
ANDRADE JÚNIOR, A.S.; RODRIGUES, B.H.N.; FRIZZONE, J.A.; CARDOSO, M.J.; BASTOS, E.A.; MELO, F.B. Níveis de irrigação na cultura do feijão caupi. Revista Brasileira de Engenharia Agrícola e Ambiental, Campina Grande, v.6, n.1, p.17-20, 2002.

AQUINO, A.J.S.; LACERDA, C.F.; BEZERRA, M.A. GOMES FILHO. E.; COSTA, R.N.T. Crescimento, partição de matéria seca e retenção de $\mathrm{Na}^{+}, \mathrm{K}^{+}$e $\mathrm{Cl}^{--}$em dois genótipos de sorgo irrigados com águas salinas. Revista Brasileira de Ciência do Solo, Viçosa-MG, v.31, n.5, p.961971, 2007.

ASSIS JÚNIOR, J.O.; LACERDA, C.F.; SILVA, F.B.; SILVA, F.L.B.; BEZERRA, M.A.; GHEYI, H.R. Produtividade do cowpea e acúmulo de sais no solo me função da fração de lixiviação e da salinidade da água de irrigação. Engenharia Agrícola, Piracicaba, v.27, n.3, p.702-713, 2007.

AYERS, R.S.; WESTCOT, D.W. A qualidade da água na agricultura. Campina Grande: UFPB, 1999. 153 p. (Estudos FAO, Irrigação e Drenagem, 29).

AZEVEDO NETO, A.D.; LACERDA, C.F.; SILVA, J.V.; COSTA, P.H.A.; GOMES-FILHO, E.; ENEAS FILHO, J.; PRISCO, J.T. Effects of salt stress on plant growth, stomatal behavior and solute accumulation of different mayze genotypes. Brazilian Journal of Plant Physiology, Piracicaba, v.16, p.31-38, 2004.

BAGHALIAN, K.; HAGHIRY, A.; NAGHAVI, M.R.; MOHAMMADI, A. Effect of saline irrigation water on agronomical and phytochemical characters of chamomile (Matricaria recutita L.). Scientia Horticulturae, Amsterdam, v.116, p.437-441, 2008.

BEZERRA, A.K.P.; LACERDA, C.F.; HERNANDEZ, F.F.F.; SILVA, F.B.; GHEYI, H. R. Rotação cultural feijão caupi/milho utilizando-se águas de salinidades diferentes. Ciência Rural, Santa Maria, v.40, n.5, p.1.075-1.082, 2010.

BLANCO, F.F.; FOLEGATTI, M.V.; GHEYI,H.R.; FERNANDES, P.D. Growth and yield of corn irrigated with saline water. Scientia Agrícola, Piracicaba, v.65, n.6, p.574-580, 2008.

DOORENBOS, J.; KASSAM, A.H. Efeito da água no rendimento das culturas. Campina Grande: UFPB, 1994. 306 p. (Estudos da FAO, Irrigação e Drenagem, 33).

EMBRAPA. EMPRESA BRASILEIRA DE PESQUISA AGROPECUÁRIA. Manual de análises químicas de solos, plantas e fertilizantes. Brasília: Embrapa Comunicação para Transferência de Tecnologia, 1999. $370 \mathrm{p}$.

EMBRAPA. EMPRESA BRASILEIRA DE PESQUISA AGROPECUÁRIA. Sistema Brasileiro de Classificação dos Solos. Brasília, 2006. 306 p.

EMBRAPA MEIO-NORTE. Sistemas de produção 2. Disponível em:

<http://sistemasdeproducao.cnptia.embrapa.br/FontesHTML/Feijao/FeijaoCaupi/clima.htm>. 2003. Acesso em: 9 mar. 2010.

FERNANDES, V.L.B. (Coord.). Recomendações de adubação e calagem para o Estado do Ceará. Fortaleza: UFC, 1993. 248 p.

FERREIRA, P.A.; GARCIA, G.O.; NEVES, J.C.L.; MIRANDA, G.V.; SANTOS, D.B. Produção relativa do milho e teores folheares de nitrogênio, fósforo, enxofre e cloro em função da salinidade do solo. Ciência Agronômica, Fortaleza, v.38, n.1, p.7-16, 2007.

FONTANELI, R.S.; SANTOS, H.P.; VOSS, M.; AMBROSI, I. Rendimento e nodulação de soja em diferentes rotações de espécies anuais de inverno sob plantio direto. Pesquisa Agropecuária Brasileira, Brasília, v.35, n.2, p.349-355, 2000.

FORNASIERI FILHO, D. Manual da cultura do milho. Jaboticabal: FUNEP, 2007. 576 p. 
FREIRE FILHO, F. R.; RIBEIRO, V.Q.; BARRETO, P.D.; SANTOS, A.A. Melhoramento genético. In: FREIRE FILHO, F.R.; LIMA, J.A.A.; RIBEIRO, V.Q. Feijão caupi: avanços tecnológicos. Brasília: EMBRAPA, 2005. cap.1. p.29-92.

GARCIA, G.O.; FERREIRA, P.A.; MIRANDA, G.V.; NEVES, J.C.L.; MORAES, W.B.; SANTOS, D.B. Teores foliares dos macronutrientes catiônicos e suas relações com sódio em plantas de milho sob estresse salino. Idesia, Arica, v.25, n.3, set/dez. 2007a.

GARCIA, G.O.; FERREIRA, P A.; MIRANDA, G.V.; OLIVEIRA, F.G.; SANTOS, D.B. Índices fisiológicos, crescimento e produção do milho irrigado com água salina. Irriga, Botucatu, v.12, n.3, p.307-325, 2007b.

GARCIA, G.O.; MARTINS FILHO, S.; REIS, E.F.; MORAES, W.B.; NAZÁRIO, A.A. Alterações químicas de dois solos irrigados com água salina. Ciência Agronômica, Fortaleza, v.39, n.1, p.7-18, 2008.

LACERDA, C.F.; ASSIS JÚNIOR, J.O.; LEMOS FILHO, L.C.A.; GUIMARÃES, F.V.A.; OLIVEIRA, T.S.; GOMES FILHO, E.; PRISCO, J.T.; BEZERRA, M.A. Morpho-physiological responses of cowpea leaves to salt stress. Brazilian Journal of Plant Physiology, Piracicaba, v.18, p.455-465, 2006.

LACERDA, C.F.; NEVES, A.L.R.; GUIMARÃES, F.V.A.; SILVA, F.L.B.; PRISCO, J.T.; GHEYI, H. R. Eficiência de utilização de água e nutrientes em plantas de cowpea irrigadas com água salina em diferentes estádios de desenvolvimento. Engenharia Agrícola, Jaboticabal, v.29, n.2, p.221-230, 2009.

LEITE, E.M.; CAVALCANTE, L.F.; DINIZ, A.A.; SANTOS, R.V.; ALVES, G.S.;

CAVALCANTE, I.H.L. Correção da sodicidade de dois solos irrigados em resposta à aplicação de gesso agrícola. Irriga, Botucatu, v.12, n.2, p.168-176, 2007.

MAAS, E.V., HOFFMAN, G.J., Crop salt tolerance: current assessment. Journal of Irrigation Drainage Division, New York, v.103, p.115-134, 1977.

MEDEIROS, J.F. Qualidade da água de irrigação utilizada nas propriedades assistidas pelo "GAT" nos Estados do RN, PB, CE e avaliação da salinidade dos solos. 1992. 173 f. Dissertação (Mestrado em Engenharia Agrícola) - Universidade Federal da Paraíba, Campina Grande, 1992.

MUNDSTOCK, C.M.; THOMAS, A. L. Soja: fatores que afetam o crescimento e o rendimento de grãos. Porto Alegre: Departamento de Plantas de Lavoura - UFRGS, 2005. 31 p.

MURTAZA, G.; GHAFOOR. A.; QADIR, M. Irrigation and soil management strategies for using saline-sodic water in a cotton-wheat rotation. Agricultural Water Management, Amsterdam, v.81, p.98-114, 2006.

NEVES, ALR.; LACERDA, C.F.; TEIXEIRA, A.D.; COSTA, C.A.G.; GHEYI, H.R. Monitoring soil coverage and yield of cowpea furrow irrigated with saline water. Ciência Agronômica, Fortaleza, v.41, n.1, p.59-66, 2010.

NEVES, A.L.R.; LACERDA, C.F.; GUIMARÃES, F.V.A.; HERNANDEZ, F.F.F.; SILVA, F.B.; PRISCO, J.T.; GHEYI, H.R. Acumulação de biomassa e extração de nutrientes por plantas de cowpea irrigadas com água salina em diferentes estádios de desenvolvimento. Ciência Rural, Santa Maria, v.39, n.3, p.758-765, 2009.

OLIVEIRA, F.A.; MEDEIROS, J.F.; OLIVEIRA, M.K.T.; LIMA, C.J.G.S.; ALMEIDA JÚNIOR, A.B.; AMÂNCIO, M.G. Desenvolvimento inicial do milho-pipoca irrigado com água de diferentes níveis de salinidade. Revista Brasileira de Ciências Agrárias, Recife, v.4, n.2, p.149-155, 2009.

PARIDA, A.K.; DAS, A.B. Salt tolerance and salinity effects on plants: a review. Ecotoxicology and Environmental Safety, New York, v.60, n.3, p.324-349, 2005.

RIBEIRO JÚNIOR, J.I. Análises estatísticas no SAEG. Viçosa: UFV, 2001. 301 p. 
RICHARDS, L.A. Diagnosis and improvement of saline and alkali soils. Washington: Salinity Laboratory, 1954. $160 \mathrm{p}$.

RITZEMA, H.P.; SATYANARAYANA, T.V.; RAMAN, S.; BOONSTRA, J. Subsurface drainage to combat waterlogging and salinity in irrigation lands in India: lessons learned in farmers' fields. Agricultural Water Management, Amsterdam, v.95, n.3, p.179-189, 2008.

RHOADES, J.D.; KANDIAH, A.; MASHALI, A.M. Uso de águas salinas para produção agrícola. Campina Grande: UFPB, 2000. 117 p. (Estudos FAO - Irrigação e Drenagem, 48).

SHARMA, D.P.; RAO, K.V.G.K. Strategy for long term use of saline drainage water for irrigation in semi-arid regions. Soil and Tillage Research, Amsterdam, v.48, n.4, p.287-295, 1998.

SILVA, E.F.; ASSIS JÚNIOR, R.M.; SOUSA, J.I.G. Efeito da qualidade da água de irrigação sobre atributos hídricos de um Neossolo. Revista Brasileira de Ciência do Solo, Viçosa-MG, v.29, n.3, p.389-396, 2005.

TIMSINA, J.; GARRITY, D.P.; PANDEY, R.K. Plant water relations and growth of cowpea cultivars subjected to varying degrees of waterlogging. Field Crops Research, Amsterdam, v.39, p.49-57, 1994. 